\title{
Lectio continua and biblical literacy within the Methodist Church
}

\author{
Ed Mackenzie
}

Dr ED MACKenzIE is a Discipleship Development Officer for the Methodist Discipleship and Ministries Learning Network (DMLN). He is also an Associate Lecturer at Cliff College and a Research Associate at CODEC.

e.mackenzie@cliffcollege.ac.uk Calver, Derbyshire, UK

Lectio continua - preaching through a single biblical book - tends to be less prominent in British Methodism than following a lectionary or a thematic series. In a context of declining biblical literacy, however, lectio continua is a fruitful way of encouraging engagement with Scripture. Following a discussion of the challenges of biblical illiteracy, this article argues that lectio continua can promote biblical literacy through its focus on whole books of Scripture, its consideration of the context of biblical passages, and its invitation to close readings of biblical texts - all key skills for reading the Bible well. A case study demonstrates how such an approach could be applied to preaching through $1 \mathrm{John}$.

BIBLE • BIBLICAL LITERACY • EDUCATION • HERMENEUTICS • HOMILETICS • PEDAGOGY • PREACHING • SCRIPTURE • 1 JOHN 


\section{Introduction}

For John Wesley, the 'man of one book', 'searching the Scriptures' was a key means of grace. Such engagement with Scripture involved three key practices: hearing the Bible, reading the Bible and meditating on the Bible. Each practice allowed Christians to encounter God's presence and grace. ${ }^{1}$

While Methodists today hold a wide range of views on the Bible, the Methodist Church continues to prioritise the importance of biblical literacy and engagement. ${ }^{2}$ The report $A$ Lamp to my Feet, a Light to my Path explains that 'the Holy Spirit speaks through the Scriptures to awaken and nurture faith and provide ethical direction for the Christian community'. In a further report, the Faith and Order Committee called for people at all levels of the Church to promote the 'reading, study and practical use of the Bible'.4

While biblical engagement remains a key focus within the Methodist Church, a decline in biblical literacy has affected those outside the Church as well as those within it. Finding ways to help people engage more deeply with Scripture, then, is important missiologically as well as in helping disciples grow.

In this article, I will argue that the practice of lectio continua - preaching sequentially through a single book of the Bible - is a helpful way of raising biblical literacy within the Church. Following a discussion of biblical illiteracy and its challenges, I will explore three ways in which lectio continua can help to promote biblical engagement: by focusing on biblical books rather than single passages, by attending to the context of Scripture, and by promoting a focused engagement with the text. The value of such an approach will be demonstrated through a case study of how lectio continua could shape preaching through 1 John. In conclusion, I will suggest that circuits and churches consider the occasional use of lectio continua as a way of helping Methodists engage more deeply with the Bible.

\section{The challenge of biblical illiteracy}

Biblical illiteracy - a lack of familiarity with the Bible's stories, characters and teachings - is a characteristic feature of the contemporary British post-Christian context. ${ }^{5}$ As Martyn Atkins has noted, 'the Bible remains for increasing numbers of people today an unknown book with unknown teaching and worst of all, an unknown God in Christ. ${ }^{6}$ The lack of familiarity with the Bible represents a 
cultural loss as well as a missiological challenge, with even Richard Dawkins lamenting the demise of the King James Version within the culture. ${ }^{7}$ Biblical illiteracy and a lack of engagement is also an issue within the Church, with fewer and fewer Christians familiar with the Bible or regularly reading it. If the Bible remains a 'means of grace' for God's people, as Methodism continues to hold that it is, then a lack of knowledge and engagement with Scripture is surely a problem for the Church. Helping people read and engage the Bible more deeply is a spiritual, as much as a pedagogical, issue.

Evidence of the decline in biblical literacy comes from a variety of sources. In a national biblical literacy survey in 2008, CODEC noted that knowledge of key Bible stories has been lost within British culture, and revealed that many found the Bible difficult to understand, boring or irrelevant. The same survey found that only 18 per cent of those who described themselves as Christian had read their Bible in the previous week. ${ }^{8}$ A 2013 survey of Bible-reading habits of British parents similarly pointed to 'an undeniable decline in our Bible literacy across the generations,' and showed that knowledge of key Bible stories had been lost within British culture.

In contrast to this picture, a recent collection of essays - Rethinking Biblical Literacy - offers a variety of perspectives that problematise the assertion that the Bible is becoming less significant within society. ${ }^{10} \mathrm{~A}$ number of essays explore echoes of biblical stories in popular culture that reflect different kinds of 'biblical literacies.11 Even where 'echoes' of the Bible exist in popular culture, however, people are less and less able to recognise them. The loss of such recognition reflects a loss of biblical literacy - in terms of knowledge about the Bible - rather than its reconfiguration.

Evangelical Christians, traditionally a constituency that has valued scriptural engagement, are also reading the Bible less. ${ }^{12}$ John Grayston suggests a number of reasons are to blame, including a loss of biblical credibility and authority, a lack of relevance, and reaction against legalistic approaches to reading the Bible. ${ }^{13}$ While there is little specific evidence of how levels of biblical literacy among Methodists compares to the wider Christian population, there is no reason to expect that it would differ markedly from the general decline.

We might pause at this point and explore further why promoting biblical literacy is so important. In the midst of so many other demands on our churches and communities, why focus on helping Methodists read and better understand the Bible? A full response to such a question would require more space than a single article, but we might simply point here to the commitment 
of the Church - historically and today - to see Scripture as a key means by which God addresses and shapes us. As the Methodist Catechism puts it, 'The Bible is the record of God's self-revelation, supremely in Jesus Christ, and is a means through which he still reveals himself, by the Holy Spirit.. ${ }^{14}$ The Deed of Union also speaks of the providence of God, by which 'Methodism was raised up to spread scriptural holiness through the land by the proclamation of the evangelical faith.15 It is precisely through engaging with Scripture that we discern what holiness - and living discipleship - actually entails. ${ }^{16}$

Given the classic role of Scripture in spiritual formation, it is not surprising that works on discipleship and spirituality point to biblical engagement as key for the life of faith. ${ }^{17}$ It is also significant that one of the greatest works on discipleship - Bonhoeffer's The Cost of Discipleship - includes an extended meditation and reflection on a text of Scripture, the Sermon on the Mount. ${ }^{18}$ In the Wesleyan tradition, Philip Meadows suggests that searching the Scriptures is significant since it involves'entering into a life-giving conversation with God, whose word of command and promise has the power to change our lives.' ${ }^{19}$

Research also shows that biblical engagement leads to spiritual growth. Reporting on an American survey that explored spiritual growth among 1,000 churches, the authors conclude that encouraging biblical engagement is the one practice that would help people at every stage of maturity to grow in faith. ${ }^{20}$ Again in the American context, research on small groups similarly highlights the importance of scriptural engagement for growing as a disciple. ${ }^{21}$

\section{Lectio continua as a response to biblical illiteracy}

While there are a number of responses to biblical illiteracy, one promising avenue for helping Methodists engage more deeply with the Bible is through lectio continua, preaching sequentially through a single book of the Bible. ${ }^{22}$ While preaching through a lectionary is a more well-known approach to engaging the Bible, lectio continua was found among many leaders of the early Church, including John Chrysostom, Origen and Augustine. It was also an approach favoured by the Reformers since it so clearly allows the biblical text to set the agenda for preaching. ${ }^{23}$

By following the biblical text across a number of sermons, lectio continua differs from lectionary preaching as well as from topical preaching. While the lectionary is an excellent resource for exposing congregations to the breadth 
of Scripture, it misses certain passages, and the priority it gives to the Gospels can lead preachers to neglect other biblical texts. Topical preaching is a helpful way to tackle particular issues in the life of the Church, but its tendency to use Scripture selectively means that it is less likely to engage deeply with a biblical book. In contrast to both approaches, lectio continua is characterised by a sustained engagement with a single biblical book, and in so doing can focus on the character, flow and story of that particular part of the canon. This does not mean that lectio continua is the 'ideal' way to construct sermons, but it does mean that it is well suited for promoting greater knowledge and understanding of the Bible.

While many Methodist churches follow the lectionary, ${ }^{24}$ there is no reason why they could not also adopt lectio continua for a limited period within the church year. Methodism makes allowance for churches to hold special Sundays with readings that depart from the lectionary, ${ }_{1}^{25}$ and a similar principle would be at work for the use of lectio continua. This would, of course, require obtaining the appropriate approval from church councils and circuit superintendents.

A possible criticism of such an approach might be that helping people engage with the Bible is part of Christian education rather than part of preaching or worship. ${ }^{26}$ The practice of lectio continua, however, has a strong historical pedigree, and some forms of preaching have always had a more educative role than others. ${ }^{27}$ Restricting biblical engagement to 'Christian education' also unhelpfully contrasts an 'educative' approach to Scripture with the 'encounter' that takes place through preaching. A careful reading of the text, however, is precisely a means through which we come to encounter God. ${ }^{28}$ As Peterson notes, 'the long and broad consensus in the community of God's people has always insisted on a vigorous and meticulous exegesis: give long and close and learned attention to this text! ${ }^{29}$

Before exploring the ways in which lectio continua can promote biblical literacy and engagement, it is worth noting that at least some empirical evidence points to its value for biblical literacy. The North Yorkshire Dales Biblical Literacy project, for example, found that one of the most effective ways to promote biblical literacy was through leading a preaching series based on a biblical book or character. ${ }^{30}$

More recently, a Bible Month pilot project run by the Methodist Church Discipleship and Ministries Learning Network (DMLN) found that preaching through a single biblical book over a series of four weeks significantly impacted the engagement of congregations with the Bible. ${ }^{31}$ Questionnaires sent to the 
four churches that took part in the project found that 61 per cent of those who responded had been encouraged to read the Bible more frequently and 59 per cent felt better equipped to read the Bible for themselves. ${ }^{32}$

In the remainder of this article, I will explore three ways in which lectio continua can help Methodists engage with Scripture. My argument will be based not so much on empirical studies - though it will highlight further work to be done in this area - but rather on homiletical and pedagogical considerations. Lectio continua can promote biblical literacy by immersing congregations in whole books rather than single texts of Scripture, by highlighting the importance of context in the act of biblical interpretation, and by modelling a focused reading of particular texts. Such an approach can also be demonstrated through a case study of how adopting lectio continua could shape preaching through 1 John.

\section{Lectio continua and reading whole texts}

The first advantage of lectio continua is that it helps congregations engage with biblical books rather than isolated texts. ${ }^{33}$ Rather than focusing on single passages, lectio continua sets biblical stories and passages within the context of the book in which they appear. ${ }^{34}$ Such an approach also encourages auditors to recognise the way in which biblical books communicate through specific genres.

On the first point, lectio continua encourages preachers to attune auditors to the 'narrative' carried by each biblical book. As biblical scholars and narrative theologians have particularly emphasised, Scripture is 'story-shaped', and even non-narrative portions of Scripture - such as the letters of Paul - assume and invoke a particular 'story' of God's action with humanity. ${ }^{35}$ Through paying attention to the story carried by each biblical book, lectio continua can remedy the tendency to sideline the wider biblical and redemptive contexts of particular passages. The prevalence of this tendency within British Methodism has been noted by Paul Kybird, who argues that many Methodists seek inspiration in 'micro-narratives' of particular Scriptures, leading to an emphasis on the 'inspirational moment' of encountering Scripture over a greater understanding of its broader context. ${ }^{36}$ Lectio continua, in contrast, encourages auditors to allow the biblical book to frame the meaning of any particular passage. 
Lectio continua also exposes auditors to the distinctive contributions of biblical genres. Apocalypses, letters and Gospels - to take just three examples function in markedly distinct ways, with the genre of each text shaping the way in which it communicates. ${ }^{37}$ John Goldingay has proposed that the various biblical genres highlight different 'models' of Scripture, and this affects how they are preached as well as interpreted. Scripture as 'Witnessing Tradition' is the best model for the narrative portions of Scripture;'Authoritative Canon' for the Law; 'Inspired Word' for the prophetic literature, and 'Experienced Revelation' for the apocalypses, Psalms, wisdom literature and the letters. ${ }^{38}$ Lectio continua can allow congregations to engage fully with these diverse ways in which God speaks through Scripture. Such an approach can demonstrate how the form of Scripture shapes its content and revelatory impact within the congregation.

Lectio continua also raises the question for auditors of how a particular biblical work fits within the canonical symphony as a whole, and so can open up fresh avenues for exploring biblical theology. ${ }^{39}$ By wrestling with the particular'word' of a biblical book - both in terms of its genre and its content - sermons can begin to tease out its connections with other canonical voices. Wesley advised preachers to 'interpret Scripture by Scripture', drawing on similar passages across the canon, and recent developments in biblical theology encourage a nuanced attentiveness to how Scripture as a whole fits together. ${ }^{40}$

The advantage of preaching through a whole book like Galatians, for example, is that a passage such as Paul's treatment of justification by grace through faith - the heart of the letter in Galatians 2:15-21 - is situated within a broader context of the revelation of God's grace to Paul (Galatians 1:11-16), scriptural support for God's redemptive grace (3:1-5:1), and Paul's exhortation that those 'in Christ' live out their freedom by walking in the Spirit (5:2-6:10). The preacher might well be daunted by the apostle's complex and scripturally rich argument, and - indeed - a glance at recent commentaries might not assuage their anxiety, ${ }^{41}$ but it is only by engaging with the breadth of Paul's argument in the letter as a whole that auditors can fully appreciate the particular point Paul makes in 2:15-21.42 Lectio continua can make it clear - for example - that Paul's trust in God's radical grace had its roots both in Paul's encounter with the risen Christ and his prayerful reflection on the Hebrew Scriptures. It can also reveal to auditors that - in Wesley's terms - 'justification' and 'new birth' always go together; God's grace to those who do not deserve it (2:15-21) is always accompanied by the gift of the Spirit that makes all things new (3:1-5; $5: 16-21){ }^{43}$ 
Through allowing congregations to immerse themselves in whole biblical books, lectio continua encourages auditors to think in terms of books and not simply single passages. It also offers an education into the way in which genre and form shape meaning. In so doing, it serves biblical literacy by modelling the way that the Bible 'works' while also encouraging readers to engage with texts by attending to the biblical book in which they occur.

\section{Lectio continua and the context of Scripture}

The second way in which lectio continua promotes biblical literacy is through highlighting the significance of the various contexts within which the book was produced. Both the historical context and the literary context of any particular passage are addressed through lectio continua, and this allows auditors to recognise the importance of such contexts in their own reading and engagement with Scripture.

The significance of understanding context in understanding texts is, of course, a basic axiom of hermeneutical theory. Taking account of context provides parameters for approaching the 'best reading' of a text, and such a reading will take account of where the text is placed - both in historical and literary terms. ${ }^{44}$ In contrast, a text removed from its original context can be co-opted into a meaning that radically reverses or negates what one scholar calls the 'communicative intention' of the text. ${ }^{45}$ Rather than encouraging an approach to the text where readers are free to entirely construct its meaning, attending to the text within context respects the text as a distinct voice that addresses the reader or auditor from its own perspective. ${ }^{46}$

The historical context of any particular book within Scripture can also be addressed in more detail through lectio continua than that which is possible in other forms of the sermon. Since the preacher and the congregation will 'take time' with the text, there is space for exploring the ways in which the text was situated in a particular time and place and addressed to specific circumstances. While drawing attention to the historical distance between text and reader may seem to detach the text from its relevance for the present, it can also be a way of drawing the reader into the 'strange new world of the Bible'.47 A skilled preacher will be able to draw parallels between ancient context and today, while also helping auditors to cultivate attention to where and when the text emerged. 
While the very act of preaching through a single biblical book raises issues of literary context, lectio continua is also an opportunity for preachers to draw attention to the immediate literary contexts of a text. Good exegetes will always note what precedes and follows any particular text, and good preachers can do the same as they follow the flow of a particular biblical book. In a context where biblical literacy was high and Christians were aware of the context of preached texts, auditors may have been implicitly aware of such links. When biblical literacy is low, however, lectio continua is an opportunity to educate auditors in how texts work across paragraphs and chapters, while encouraging an encounter with the living Christ who speaks through the whole of Scripture. ${ }^{48}$

A preacher on Micah might be tempted to dwell on the prophecy of a ruler from Bethlehem (5:2-5), or on the famous explanation of what the Lord requires: 'to do justice, and to love kindness, and to walk humbly with your God' (6:8). Lectio continua, however, will allow preachers to place such texts in context, noting the historical context of eighth-century Judah and Micah's place among the biblical prophets. In terms of the literary context, a preacher might note that the book as a whole falls into three key sections, each of which begins with punishment and ends with the promise of restoration (1-2; $3-5 ; 6-7) .{ }^{49}$ Hence, the prophecy of the ruler from Bethlehem (5:2-5) comes as part of a series of restoration oracles (4:1-5:15), all of which follow the critique of Judah's rulers in chapter 3 . The description of what the Lord requires in 6:8, in contrast, is part of a broader lament within Micah that explains how God's people are precisely not those who fulfil God's calling (6:1-16), and so sets the scene for the promise of divine restoration in 7:8-20. Such restoration relies wholly on divine compassion and the willingness of God to shepherd his people and forgive their sins (7:14-19). The understanding of a particular text is enriched by placing it within the wider context of the work. ${ }^{50}$

Lectio continua can promote biblical literacy among the congregation, then, by modelling to auditors the importance of attending to the contexts of biblical passages. By hearing the preacher address the way a passage is rooted historically and in its literary setting, auditors can be encouraged to take account of such contexts in their own reading of Scripture. Preaching through a biblical book will still, of course, provide an opportunity to encounter and hear God, but lectio continua allows this to take place in the midst of a contextual engagement with the biblical text. 


\section{Lectio continua and engaging the text}

A third advantage of lectio continua is that it encourages the preacher and auditors to remain focused on the text as the primary locus of meaning within the preaching event. Such focus lends itself to a close and careful reading of biblical passages and encourages auditors to cultivate similarly attentive readings of Scripture. It can also lead preachers to model ways of addressing difficult or seemingly pedestrian texts within the biblical canon.

The priority of the Bible in preaching has been called for by a number of different preachers and theologians. This was, of course, a key emphasis in the theology of Karl Barth, who explained that 'the preacher's task is to cause the testimony presented in the text to be heard ... preaching is good if it brings to life in this present age the testimony of the prophets and the apostles.51 In the Methodist Church, the Conference report Called to Love and Praise proposes that one of the characteristics of a church community will be'preaching which engages with contemporary life and with the Bible at depth and with integrity'.52 Neil Richardson has also argued that the renewal of the Church is always associated with 'biblical preaching'. Such preaching will prioritise the biblical text, and acts as an invitation 'not only to immerse ourselves in the Bible, but to live, breathe and be transformed by it..53 The UMC Bishop William Willimon similarly notes that 'Preaching is Christian only when it is biblical, when it is obviously derivative of, submissive to, and controlled by the biblical word. ${ }^{54}$ While lectio continua is not the only means to achieve such 'biblical preaching', it is at least one way in which engagement with Scripture is prioritised for the congregation as a whole.

By engaging with the same biblical book over a number of sermons, lectio continua promotes a close and careful reading of biblical texts. The preacher's immersion in the text, ${ }^{55}$ and the sermons preached on it, can nurture the auditor's own engagement and understanding of Scripture. Such an approach would give careful attention to the 'rhetoric' of the text, which Walter Brueggemann describes as the first step in biblical interpretation. ${ }^{56}$ Attending to the rhetoric requires careful observation of the literary features of the text, such as key words, repetitions and parallel expressions. Close reading will also allow the particular features and content of the text to come to light within the broader contexts already addressed. ${ }^{57}$ Lectio continua is not a context for the preacher to 'show off' exegetical skill or acumen, but it is an opportunity for showing how a close reading of the text yields up the riches of the biblical word. ${ }^{58}$ 
Lectio continua requires that preachers explore every passage within a biblical book. This includes 'problem passages', which, in their very distance from the contemporary world, encourage auditors and readers to wrestle more deeply with the biblical word.59 ${ }^{59}$ The preacher will also encounter apparently 'pedestrian texts' that nonetheless have a role within the formative power of Scripture. A preacher addressing a text such as 1 Timothy 5:3-16 might be struck by the historical and cultural difference between widows in the first century and widows today, and might wonder what to make of the 'list' for older widows and the instructions to young widows to remarry (5:14). Such a text will seem irrelevant to some and fairly problematic to others. Lectio continua requires that such texts receive attention, and gives preachers an opportunity to model a 'hermeneutics of trust' that reveals the sweetness of the word even in unexpected places.

Engaging the Bible through lectio continua serves biblical literacy, then, by highlighting the centrality of Scripture and modelling a close reading of the text through the preaching event. Lectio continua can also lead to sermons on passages that are difficult or seemingly pedestrian, and so models and encourages auditors to engage with such texts in their own 'searching of the Scriptures'.

\section{Lectio continua and 1 John: a test case}

My argument so far has been that lectio continua can help promote biblical literacy within the Methodist Church. It can do so by encouraging preachers to focus on whole books of the Bible, draw attention to literary and historical contexts in understanding texts, and prioritise close readings of biblical books. While other forms of preaching need not exclude such emphases within the sermon, lectio continua is particularly well suited to focusing on the distinct voices of different biblical books.

Such a way of preaching the Bible models how to read Scripture well, and it is this that promotes biblical literacy. Lectio continua helps auditors to enter the world of Scripture and, through engaging with a single biblical book, to better hear and appreciate particular canonical voices. It shows the rewards of attending closely to each part of the Bible and so can encourage auditors in their own reading of Scripture. 
To reiterate a point made earlier, this does not mean that sermons become lectures in exegetical method, or that those seeking the bread of divine encounter are given the stone of human learning. It is, however, to recognise that hearing God's word requires attentiveness to the shape and scope of the stories and arguments the Bible tells.

While brief examples of how this might affect preaching have been included above, it may be helpful at this point to explore how lectio continua might affect the preparation and delivery of a series of sermons on a single biblical book, such as 1 John. As a fairly short book - and a favourite of John Wesley's ${ }^{60}-1$ John seems a suitable test case. Rather than offering examples of what a series of sermons on 1 John might look like, I will focus here on how lectio continua can shape the delivery of sermons on this first-century letter and so model the importance of reading the Bible well.

Lectio continua would allow a preacher to pay attention, first, to the way in which the biblical book of 1 John works as a whole, and would allow each sermon to be framed in light of the purpose and theme of the overall letter. The preacher could explain that 1 John is a book concerned both with 'right belief' about Christ, since by knowing Christ rightly we know the Father (2:2225), and also with 'right living', since loving others is a response to God's love displayed so radically in the Cross $(4: 7-11){ }^{61}$

A preacher could also explore the rhetorical and literary 'shape' of 1 John, the way in which its form shapes its content: 1 John is a letter - albeit a fairly homiletical letter ${ }^{62}$ - that was written to a particular community with specific concerns. ${ }^{63}$ The letter also reflects the literary style of the Johannine literature. Whereas Paul's arguments develop step by step, the letter of 1 John continually revisits and develops its key concerns. The preacher might point out that a particular passage receives development later in the letter, such as the call to love in 1:10 seeing further expansion in 4:7-21.

The historical context of 1 John would also be addressed through lectio continua. A preacher could note that the writer addresses a community threatened by false teachers who advocated an inadequate view of Jesus and failed to love others ( 1 John 2:7-11, 18-25). They had, in fact, departed from the author's community ( 1 John 2:18-19). While the author's Christology and admonitions of love are directed to such a context, a preacher can draw parallels with the present, such that the biblical word speaks to the contemporary questions of faith and practice. ${ }^{64}$ What are the challenges to 'right belief' and 'right living' today? 
Lectio continua can also provide an opportunity for the preacher to acknowledge the literary context of particular passages. A text such as $1 \mathrm{John}$ 3:4-10 - and its declaration that 'no one who abides in him sins' - can be read alongside the earlier acknowledgement that those who do sin receive forgiveness (1 John 1:5-2:2). The letter as a whole provides parameters for understanding the meaning of its particular sections, but also - in this instance - raises the issue of how holiness and forgiveness relate to one another throughout the Bible. Such a reading of Scripture is related to the broader question of 'entire sanctification' within Methodist theology, and here, as elsewhere, wrestling with a biblical text leads to issues of wider theological importance.

Finally, as lectio continua allows the preacher (or team of preachers) to move from text to text, they can spend time delving into the rhetorical impact and meaning of particular passages. A close rhetorical reading of 1 John 2:23-29, for instance, would note the way in which the whole text is set within the context of the 'last hour' (2:18), an eschatological reference that a preacher could choose to unpack. ${ }^{65}$ More significantly, the focus on what the antichrists 'deny' (2:22), where the verb (Gk: arneomai) occurs three times, points to the need to think rightly about Christ (or accept the true Christ, cf., 5:20) that energises the letter as a whole. The most significant word in this short passage, however, is the verb 'remain' (Gk: menō), occurring five times here and twentyfour times in 1 John as a whole, while also being a key term within the wider Johannine literature. ${ }^{66}$ This passage suggests that 'remaining' in Christ is inseparable from 'remaining' in the truth that has been received (2:24). Such a passage could challenge the contemporary tendency to separate spirituality and doctrine.

While 1 John 2:23-29 is far from pedestrian, its warning of antichrists and its obscure references to christological error may make it offensive to modern readers. When it occurs in the lectionary, a preacher could easily avoid the issues it raises in favour of a reading more amenable and accessible to the congregation. Yet it is precisely here where lectio continua challenges preachers and congregations to wrestle with the whole of Scripture, and to recognise each canonical voice - even the difficult ones - as a vehicle for God's grace within the gathered community. 


\section{Conclusion}

I have argued in this paper that lectio continua is particularly well suited for promoting biblical literacy within the Church. It allows preachers to model a close and careful reading of Scripture through the sermon, and so helps auditors to learn what it means to listen carefully to the distinctive voice of different parts of Scripture. Those who hear such sermons can be encouraged to read the Bible equally attentively in personal devotion or small-group settings.

While lectio continua is not the only approach to encouraging biblical literacy, it can be a helpful addition to other ways in which Methodists are encouraged to engage with Scripture. It can also supplement other forms of preaching, such as the use of the lectionary or topical preaching. The value of such an approach to biblical literacy could also be usefully explored through empirical study.

Lectio continua is good for biblical literacy because it prioritises the biblical book as the broader context for every biblical text. Auditors will be encouraged to think in terms of books rather than passages, and so will more likely keep in mind the whole biblical book while reading Scripture in personal devotion or in small groups.

Lectio continua also promotes biblical literacy by drawing attention to the historical and literary contexts of particular texts. While good preachers will not ignore these contexts in any approach, lectio continua provides an opportunity to explicitly relate particular scriptural passages to the history of the text and to the surrounding passages.

Finally, lectio continua is good for biblical literacy because it emphasises that the Bible is central for sermons, and that even difficult or seemingly mundane texts form part of the scriptural word. By signalling the priority the Church gives to Scripture, lectio continua encourages auditors to 'take up and read' texts for themselves.

For Methodists churches, circuits and districts seeking to engage people more deeply with Scripture, lectio continua should be considered as an approach to preaching that can serve this end. This need not displace the use of the lectionary, but can occasionally be adopted as part of an intentional focus on helping congregations engage with Scripture. 
Preaching lectio continua within a church or across a circuit will of course need to be approved by the superintendent and addressed within the local preachers' meeting. Forward planning would clearly be required, and a team of preachers might need to work together to prepare a series of sermons focused on the same biblical book. The DMLN Bible Month pilot project, however, shows that it is possible for such a model to work, and the experience can be rewarding for preachers as much as for congregations. ${ }^{67}$

Adopting lectio continua as an occasional approach within the circuit preaching plan would not only promote better biblical engagement but also allow preachers to develop their own engagement with the text. It will allow auditors and readers to say again with the Psalmist, 'How sweet are your words to my taste, sweeter than honey to my mouth!' (Psalm 119:103).

\section{Notes}

1. For Wesley's view of the Bible, see Maddox 2012.

2. In this article, biblical literacy refers to an individual's knowledge of the biblical text while biblical engagement refers to the regular'searching of the Scriptures' encouraged so strongly by Wesley. Killingray's contention (1997, p. 3) that biblical literacy is also a 'matter of the knowledge of the God revealed in the Bible's pages' confuses transformation by the God of Scripture with knowledge of Scripture itself, although - of course - the two should always be connected.

3. The Methodist Church 1998, p. 34.

4. Available at www.methodist.org.uk/downloads/conf-the-nature-of-authority2001.pdf. Accessed 1 October 2015. Italics original.

5. While biblical illiteracy refers to the lack of explicit knowledge of the Bible, it is of course - intimately connected to a lack of biblical engagement. Those who read the Bible regularly will have a greater knowledge of it than those who do not.

6. Atkins 2010, p. 38.

7. www.theguardian.com/science/2012/may/19/richard-dawkins-king-jamesbible. Accessed 1 October 2015.

8. For details, see the 'Briefing Sheet \#2: The National Biblical Literacy Survey'(2011) available at www.dur.ac.uk/resources/cblc/BriefingSheet2.pdf. Accessed 15 September 2015.

9. See the Bible Society's Report, Pass it On (2013) at www.biblesociety.org.uk/ uploads/content/projects/Bible-Society-Report_030214_final_.pdf. Accessed 15 August 2015.

10. Edwards 2015.

11. Edwards uses the phrase 'biblical literacies' in her Introduction, and notes that the volume includes a variety of perspectives, Edwards 2015, pp. ix-x. The first essay, for example, adopts a conventional approach to biblical literacy to argue for its loss in the Republic of Ireland (Byrne 2015). 
12. Grayston 2002. See also the more recent research of the Evangelical Alliance 2011, p. 14, which shows that Christians in older age brackets are more likely to read or listen to the Bible daily.

13. Grayston 2002. For a similar list of reasons, see Killingray 1997, pp. 5-7.

14. The Methodist Church 2010, p. 28; Question 52.

15. The Methodist Church 2015, p. 213.

16. On this point, see Atkins 2010, pp 36-37. As Atkins puts it, Scripture is 'God's manual for Christian disciples', p. 36.

17. See, for example, the extended engagement with Scripture in book 3 of Eugene Peterson's Spiritual Theology, Peterson 2006.

18. Bonhoeffer 1948. In his treatise Life Together, Bonhoeffer also called for the reading and meditation of Scripture to be central, and encourages the practice of lectio continua within community! Bonhoeffer 1954, pp. 35-37.

19. Meadows 2013, p. 7.

20. Hawkins and Parkinson 2011, p. 19.

21. Bible engagement is identified as one of eight 'areas' of discipleship that help Christians grow by Stetzer and Geiger 2014, p. 39. Roger Walton's research among church small groups in the north-east of England does not directly address the role of Scripture, but does show how such groups focused on personal growth and mutual support, and so are rarely 'missional', Walton 2011. In my view, an equally significant concern is the way that such groups encourage a privatised view of faith such that there is 'little stomach for debating truth claims or doctrine' (Walton 2011, p. 110). For a helpful overview of small groups within history and today - and some theological reflections on their status - see Walton 2014, pp. 67-156.

22. For a brief discussion of lectio continua alongside other approaches to the sermon - and a discussion of its advantages and drawbacks - see Farris 1998, pp. 45-51, and Long 2005, pp. 69-75.

23. While it is Zwingli who is the strongest advocate for lectio continua among the mainstream Reformers, Luther and Calvin also adopted lectio continua as one of their approaches. For a discussion of lectio continua among the Reformers, see the relevant sections in Old 2002, pp. 1-157. On Zwingli in particular, see Old 2002, pp. 46-47.

24. For a brief discussion on the use of the lectionary, see the discussion in Dixon 2003, pp. 225-226.

25. For examples of such Sundays, see www.methodist.org.uk/prayer-andworship/methodist-special-sundays. Accessed 15 January 2016. While some 'special Sundays' do follow the lectionary, others - such as Refugee Week - select readings specific to the theme.

26. This might be a possible reading of Roger Walton's description of 'Christian education' as a set of activities that serve the 'primary energies' of discipleship which Walton identifies as 'worship', 'community' and 'mission' (2014, especially pp. 41-61). See also Stephen Wright, who argues that sermons should be primarily about encounter rather than 'education' into the meaning of the faith, since such education can take place in other ways (2010, pp. 165-166). 
27. Stephen Wright, for example, describes the 'teaching sermon' as an approach that is particularly good at allowing for the 'greater development of ideas' (2010, p. 148). Other sermons can be described as 'liturgical', 'evangelistic' or 'street' sermons, although Wright acknowledges that the distinctions between these are sometimes blurry (2010, pp. 141-152).

28. See Bonhoeffer's critique of those who would see learning the Scriptures as 'too profane a purpose' for worship (1954, p. 36).

29. Peterson 2006, p. 50. Peterson means by 'exegesis' a careful and close reading of the text rather than a specialist skill reserved for the experts.

30. Wood 2013, p. 23.

31. The pilot project took place in 2014, and a (unpublished) report is available from Ed Mackenzie, Discipleship Development Officer, Discipleship and Ministries Learning Network (mackenziee@methodistchurch.org.uk).

32. Significantly, the report also indicates that 80 per cent of those surveyed wanted their church to hold a similar 'Bible Month' at a future date.

33. The Community Bible Experience, a Biblica initiative that encourages reading through the Scriptures in community, suggests three reasons for the decline in biblical engagement: 'reading the Bible out of context', 'reading the Bible in fragments' and 'reading the Bible in isolation'. All of these reasons are addressed through lectio continua, but the Community Bible Experience is also a commendable attempt to encourage reading Scripture together. See www.biblicaeurope. com/why-community-bible-experience. Accessed 15 October 2015.

34. For a similar plea that passages be read in the contexts in which they occur, see Thomas 1987, p. 47. Thomas recommends the use of the lectionary as a way to expose congregations to the whole of Scripture, although the argument for lectio continua is that it allows a more focused engagement with a single biblical book.

35. In Pauline studies, one classic demonstration of this point is Richard B. Hay's seminal study (Hays 1983). On the importance of the 'story' of Scripture, see N. T. Wright 1991; 2005, pp. 17-20; Brueggemann 1997, pp. 24-37; 2009, pp. 1-11; Peterson 2006, pp. 37-58.

36. Kybird 2012. Peterson describes such 'privatising' of Scripture as one way Scripture becomes distorted (2006, p. 46). On such a tendency within small groups, see Walton 2014, pp. 108-122, and Withrow 2003. Withrow suggests that linking the small-group discussion to the biblical narrative is one way to avoid such privatised approaches to faith.

37. On the general importance of biblical genres and a brief overview, see Brown 2007, pp. 139-165.

38. In an initial volume, Goldingay (1994) introduces these different models of Scripture. In a second volume (1995), he focuses on different ways to interpret and then preach - the biblical books associated with each model.

39. For the importance of this task, see Scobie 2004.

40 For the way in which Wesley read Scripture 'comparatively' with other texts in the canon, as well as alongside scholarly tools and within other contexts, see Maddox 2012.

41. Exegetical discussions are legion on issues such as the meaning of 'justification', 
'works of the law', 'faith in/of Jesus Christ', and Paul's seemingly peculiar interpretation of the Old Testament Scriptures. For a recent commentary to Galatians that engages helpfully with some of the key debates, see Oakes 2015.

42. Lectio continua also allows the preacher to reflect on the way in which the letter form shapes the content while also reflecting Paul's personal - and apostolic relationship with the first readers of the text.

43. This could then lead to an exploration of the same twin dynamics within Scripture. For Wesley, 'justification' and the 'new birth' were the central features of Christian faith - see especially his sermon on 'The New Birth' (sermon 45), available at wesley.nnu.edu/john-wesley/the-sermons-of-john-wesley-1872edition/sermon-45-the-new-birth. Accessed 1 October 2015.

44. Brown 2007, pp. 189-231; N. T. Wright 2005, pp. 93-95. The 'canonical context' is also a particular concern of biblical theology (Scobie 2004).

45. Brown 2007, pp. 79-99. Brown's approach to the 'communicative intention' of scriptural texts acknowledges both that texts are'complex' and that they are also 'determinate' so that it is possible to judge between good and bad readings. For a 'critical realistic' approach to Scripture that similarly affirms the possibility of hearing 'rightly' while also acknowledging the difficulties, see N.T. Wright 1992, pp. 47-80. As Briggs also notes, reading Scripture on its own terms opens us up to God's agenda (2007, p. 176).

46. Contemporary hermeneutics acknowledges that the reader will have some role in 'constructing' the meaning, but there is a danger if such an acknowledgement is treated as a warrant to project one's own agenda on to the text. On the importance of allowing the text to speak for itself, see Briggs 2007. See also Hay's (1997) qualified critique of a 'hermeneutic of suspicion' in favour of a 'hermeneutic of trust' that is open to God speaking through the Scriptures.

47. The phrase comes originally from Karl Barth (1995).

48. As noted earlier, a dichotomy between a sermon as 'educative' and a sermon as leading to 'encounter' with God can be unhelpful. A sermon should not, of course, be an exegetical lecture, but good preachers can nonetheless draw auditors into the flow of a text through noting some of the obvious connections between passages.

49. For a discussion of this structure, see Waltke 2007, pp. 13-16.

50. While churches often adopt a 'folk canon' that is selective in the texts that are preached - so, for example, prioritising well-loved passages such as Micah 6:8 this can lead preachers and auditors to ignore the wider context of the text. For a similar concern and a plea for churches to engage with the whole canon (and especially the Old Testament), see Thomas 1987.

51. Barth 1964, p. 105. While Barth develops this idea in far more detail in the Church Dogmatics, he explains in his little book on preaching that 'the views expressed there [in the Church Dogmatics] are essentially the same as those of this earlier work, though argued and formulated in slightly different terms' (p. 64).

52. The Methodist Church 1999, p. 31.

53. Richardson 2011, p. 41.

54. Willimon 2005, p. 33. 
55. For the importance of such immersion in the text, see Barth 1964, pp. 101-104.

56. Brueggemann 2009, pp. 30-52. For Brueggemann, such rhetorical analysis takes priority over issues such as historical interpretation. See also Brown 2007, pp. 139-165.

57. Peterson's reflections on the importance of 'exegesis' for the spiritual life are again apposite here (2006, pp. 49-58).

58. Brown notes that while readings can be 'determinate' they are never 'exhaustive', and so a close reading of the text can always lead to new discoveries (2007, pp. 83-88).

59. On this point, see Briggs (2007), who claims that problem passages help readers listen to Scripture on its own terms. 'Problem passages' refers to those texts that present ethical, moral or theological difficulties for contemporary readers (eg, texts dealing with Israel's slaughter of the Canaanites).

60. According to Maddox (2012, pp. 11-12), Wesley preached more on this text than any other.

61. For a fuller exploration of $1 \mathrm{John}$, including its key theological themes, see Lieu 1991, and the relevant sections of Kruse 2000 and Yarbrough 2008. For a particular rich treatment of Johannine theology that includes reference to 1 John, see Rainbow 2014.

62. The particular genre of 1 John continues to be discussed, but Kruse offers a persuasive recent defence of 1 John as a (circular) letter (2010, pp. 28-29).

63. In Goldingay's terms, 1 John represents 'experienced revelation' within the canon, and so needs to read differently than a law book (although it includes instruction, as in 4:7-12) or a narrative (although it appeals to story, such as in 1:1-3).

64. On the task of 'contextualising' the biblical message for today, see the helpful discussion of Brown 2007, pp. 232-272.

65. For an exegesis of this text - and the significance of the 'last hour' - see Yarbrough 2008, pp. 141-145.

66. On the significance of 'abiding' (or 'remaining') in Christ within the Johannine literature, see Rainbow 2014, pp. 313-350. As Rainbow points out, for the Johannine literature, '[t]o abide in Christ is the basic mode of Christian existence and discipleship' (p. 323).

67. Building on the pilot project mentioned above, the DMLN is exploring the development of resources to help churches interested in running 'Bible Months' focused on particular biblical books.

\section{Bibliography}

Atkins, Martyn. 2010. Discipleship and the People Called Methodists. London: The Methodist Church.

Barth, Karl. 1964. Prayer and Preaching. London: SCM Press.

Barth, Karl. 'The Strange New World within the Bible', in Braaten, Carl E. and Robert W. Jenson (eds). 1995. A Map of Twentieth-Century Theology: Reading from Karl Barth to Radical Pluralism. Minneapolis, MN: Augsburg Fortress, pp. 21-30.

Bonhoeffer, Dietrich. 1948. The Cost of Discipleship. London: SCM Press. 
Bonhoeffer, Dietrich. 1954. Life Together. London: SCM Press.

Briggs, Richard S. 2007. 'The Role of the Bible in Formation and Transformation: A Hermeneutical and Theological Analysis', Anvil 24(3): 167-182.

Brown, Jeannine K. 2007. Scripture as Communication: Introducing Biblical Hermeneutics. Grand Rapids, MI: Baker Academic.

Brueggemann, Walter. 1997. Cadences of Hope: Preaching among Exiles. Louisville, KY: Westminster John Knox Press.

Brueggemann, Walter. 2009. Redescribing Reality: What We Do When We Read the Bible. London: SCM Press.

Byrne, Máire. 'Biblical Literacy: The Irish Situation', in Edwards, Katie (ed.). 2015. Rethinking Biblical Literacy. London: Bloomsbury T \& T Clark.

Dixon, Neil. 2003. Wonder, Love and Praise: A Companion to the Methodist Worship Book. Peterborough: Epworth Press.

Edwards, Katie (ed.). 2015. Rethinking Biblical Literacy. London: Bloomsbury T \& T Clark. Evangelical Alliance. 2011.21st Century Evangelicals: A Snapshot of the Beliefs and Habits of Evangelical Christians in the UK. London: Evangelical Alliance.

Farris, Stephen. 1998. Preaching that Matters: The Bible and Our Lives. Louisville, KY: Westminster John Knox Press.

Goldingay, John. 1994. Models for Scripture. Grand Rapids, MI: Eerdmans.

Goldingay, John. 1995. Models for Interpretation of Scripture. Grand Rapids, MI: Eerdmans.

Graystone, John. 2002. 'The Bible and Spirituality: The Decline in Biblical Literacy among Evangelicals and the Future of the Quiet Time', Anvil 19(2): 99-107.

Hays, Richard B. 1983. The Faith of Jesus Christ: An Investigation into the Narrative Substructure of Galatians 3:1-4:11. Chico, CA: Scholars Press.

Hays, Richard B. 1997. 'Salvation by Trust? Reading the Bible Faithfully', The Christian Century: 218-223.

Hawkins, Greg L. and Parkinson, Cally. 2011. Move: What 1,000 Churches Reveal about Spiritual Growth. Grand Rapids, MI: Zondervan.

Killingray, Margaret. 1997. Encouraging Biblical Literacy. Cambridge: Grove Books.

Kruse, Colin G. 2000. The Letters of John. Grand Rapids, MI: Eerdmans.

Kybird, Paul. 2012. Belonging and Believing: The Dilemma of Methodist Identity. Methodist Sacramental Fellowship.

Lieu, Judith. 1991. The Theology of the Johannine Epistles. Cambridge: Cambridge University Press.

Long, Thomas G. 2005. The Witness of Preaching. 2nd edn, Louisville, KY: Westminster John Knox Press.

Maddox, Randy L. 'John Wesley - "A Man of One Book"', in Green, Joel B. and Watson, David F. (eds). 2012. Wesley, Wesleyans and Reading the Bible as Scripture. Waco, TX: Baylor University Press, pp. 3-18.

Meadows, Phil. 2013. Wesleyan DNA of Discipleship: Fresh Expressions of Discipleship for the 21st Century Church. Cambridge: Grove Books.

The Methodist Church. 1998. A Lamp to My Feet, a Light to My Path. Peterborough: Methodist Publishing House. 
The Methodist Church. 1999. Called to Love and Praise. Peterborough: Methodist Publishing House.

The Methodist Church. 2010. A Catechism for the Use of the People Called Methodists. Peterborough: Methodist Publishing House.

The Methodist Church. 2015. The Constitutional Practice and Discipline of The Methodist Church, vol. 2. London: Methodist Publishing House.

Oakes, Peter. 2015. Galatians. Grand Rapids, MI: Baker Academic.

Old, Hughes Oliphant. 2002. The Reading and Preaching of the Scriptures in the Worship of the Christian Church, vol. 4: The Age of the Reformation. Grand Rapids, MI: Eerdmans.

Peterson, Eugene H. 2006. Eat this Book: A Conversation in the Art of Spiritual Reading. London: Hodder and Stoughton.

Rainbow, Paul. 2014. Johannine Theology: The Gospel, the Epistles and the Apocalypse. Downers Grove, IL: InterVarsity Press.

Richardson, Neil G. 2011. 'Preaching, the Bible and the Renewal of the Church.' Epworth Review (April): 38-48.

Scobie, Charles H. H. 'Biblical Theology and Preaching', in Bartholomew, Craig, Healy, Mary, Möller, Karl and Parry, Robin (eds). 2004. Out of Egypt: Biblical Theology and Biblical Interpretation. Grand Rapids, MI: Zondervan.

Stetzer, Ed and Geiger, Eric. 2014. Transformational Groups: Creating a New Scorecard for Groups. Nashville, TN: B\&H Publishing Group.

Thomas, Timothy L. 1987. 'The Old Testament "Folk Canon" and Christian Education', The Asbury Theological Journal 42(2): 45-61.

Waltke, Bruce K. 2007. A Commentary on Micah. Grand Rapids, MI: Eerdmans.

Walton, Roger. 2011. 'Disciples Together: The Small Group as a Vehicle for Discipleship Formation', The Journal of Adult Theological Education 8(2): 99-114.

Walton, Roger L. 2014. Disciples Together: Discipleship Formation and the Role of Small Groups. London: SCM Press.

Willimon, William H. 2005. Proclamation and Theology. Nashville, TN: Abingdon Press. Withrow, Lisa R. 2003. 'Disciples for the Future: Small Groups and Vital Faith Development', Quarterly Review: A Journal of Theological Resources for Ministry 23(2):141-150.

Wood, David, 2013. Let the Bible Live: Report of the North Yorkshire Dales Biblical Literacy Project. Durham: CODEC.

Wright, N. T. 1991. 'How Can the Bible be Authoritative?', Vox Evangelica 21: 7-32.

Wright, N. T. 1992. The New Testament and the People of God. London: SPCK.

Wright, N. T. 2005. Scripture and the Authority of God. London: SPCK.

Wright, Stephen I. 2010. Alive to the Word: A Practical Theology of Preaching for the Whole Church. London: SCM Press.

Yarbrough, Robert W. 2008. 1-3 John. Grand Rapids, MI: Baker Academic. 